\title{
Housing Habitability of the Elderly in Selected Rural Communities of Ibadan, Oyo State, Nigeria
}

\section{Popoola Kehinde Olayinka (Ph.D.)}

Obafemi Awolowo University, Ile-Ife, Nigeria Urban and Regional Planning Email: yinkaolayiwola@yahoo.co.uk

\section{Doi:10.5901/mjss.2016.v7n4p}

\begin{abstract}
The study examined the housing habitability of the rural elderly in selected rural communities of Ibadan, Oyo state, Nigeria. Multi-stage sampling technique was used for the survey. Four of the six local government areas in the hinterlands of Ibadan (Akinyele, Egbeda, Ido and Lagelu) were randomly selected. Three rural settlements were selected from each of the selected local government areas using simple random sampling method. The settlements are: Onidundu, Ojedeji, Obada, Idioro, Owobaale, Olodan, Ajiwogbo, Odebode Elere, Odetola, Abaedun, Lalupon, and Oyedeji. The sample size was determined by a snowball sampling technique where an elderly was located and the rest were referred in the study area. A total of 265 duly completed questionnaires administered to the elderly (age 60years and above) in each sampled household were used. It was discovered in the study that the rural elderly with habitable houses are those with better annual income, occupation and educational status. The study also revealed that the higher the age of the elderly, the poorer the housing facilities available for them to utilize. This study therefore concluded that many of the houses were inhabitable for the rural elderly which is an indicator of unlivable rural communities for the elderly.
\end{abstract}

Keywords: Housing, Housing habitability, Elderly, Rural Communities

\section{Introduction}

The house a man lives in, is a symbol of his status, a measure of his achievements, an expression of his personality and the barometer that indicates the way he is perceived by the society (Okupe in Eke, 2004). It is an indicator of the standard of living of the people and their place in the society (Nubi, 2008). The World Health Organization (WHO) described housing as residential environment which includes the physical structure used for shelter, all the necessary services, facilities, equipment and devices needed or desired for the physical and mental health and social wellbeing of the family and individuals. There are different characteristics a house should possess to make it standard for habitation. For instance, Wahab (2001) explained that a house is habitable if the internal and external facilities are present. These facilities include; waste disposal facilities, water facilities, electricity facilities, sanitary facilities, durable building materials and all that make a house habitable. Housing situation in Nigeria is however characterized by inadequacies that are qualitative and quantitative in nature. The problem of housing is experienced both in the urban and rural areas of the country.

Rural housing problems in Nigeria are viewed mostly in terms of the quality of the houses and their environment. Men, Hall and Roberts (2006) described housing quality as the level of acceptability of dwelling units including the design and functionality of housing structures, building materials used, the amount of internal and external space pertaining to the dwelling, housing utilities and basic service provision. In the rural areas of Nigeria, most of these services are limited or not available. This makes houses in these communities uninhabitable for the residents especially the rural elderly. The rural elderly face lots of housing habitability challenges because of the limited or non-existent of social services and infrastructural facilities (IFAD, 2007). The kind of housing condition the young may bear to live in might be very uncomfortable for the elderly. This is because the elderly are very vulnerable (World Bank, 1994) due to their physical weakness, powerlessness and isolation which continue to wage poverty against them (Kolawole and Torimiro, 2006).

Housing habitability in rural areas constitute major challenges in Nigeria. However, these challenges are scantly addressed in researches and policies in spite of the significant place the rural areas hold in the country. Again housing condition of the elderly in the rural areas of Nigeria requires greater attention because of the vulnerable nature of the elderly. Available studies on elderly housing (Banks et al, 2012; Gardener, 2004; Painter and Lee, 2009; Lee and Painter, 2012; Oldman, 2014) are more in developed countries. Studies on elderly housing especially in the rural areas of Nigeria 
have not been properly articulated. It is against this background that the study examined the Housing Habitability of the Elderly in selected Rural Communities of Oyo State, Nigeria. The questions addressed in this paper are: 1) what are the housing condition of the elderly in the selected rural communities? and 2) what are the determinants of their housing condition

\section{Conceptual Issues}

Akinola (1998) defined housing as a unit having essential facilities like water supply, electricity, bathroom, toilet, kitchen which permit sufficient comfort and convenience. It embraces all social services and utilities that make a community or neighborhood a livable environment (Aribigbola, 2008). It is a process of providing functional shelter in a proper setting of a neighborhood, supported by sustainable maintenance of the built environment for the day to day living, activities of individual and families within the communities (National Housing Policy, 2006).

Geographically, there are two categories of housing. They are urban and rural housing. Urban housing in Nigeria are houses in settlements having populations above 20,000 while rural housing in Nigeria are houses found in settlements of less than 20,000 people and where their major occupation are primary occupations. Rural housing can be categorized based on type of rural settlements and these settlements vary by degree of permanency. They are: i. Farmstead housing settlements defined as settlements having less than 50 buildings ii. Hamlet housing settlements have between 51-100 buildings and iii. Village housing settlements defined as settlements having more than 100 buildings (UN Habitat Global Report on Human Settlement, 2009). Residents of rural housing consist of young and old, men and women. They all face various degrees of risk such as unavailability of basic infrastructural facilities such as water supply, electricity, among other facilities.

The elderly in rural housing face the greatest challenges due to their vulnerability nature. This might not be farfetched from the fact that majority of them are no longer in the economically active phase of life. World Bank (2000) sees the elderly as those age 60years and above where poverty have singled them out as one of the groups experiencing deprivation because of their stage in life cycle. Lloyd Sherlock (2000) explained that aging diminishes the capacity to work and earn. This in turn reduces their capacity for income generation and thus increase their vulnerability to fall into poverty regardless of their original economic status. This makes it very difficult for the rural elderly to cope with their living condition especially their housing habitability challenges. Well-being is largely determined by the condition of housing occupied which in turn is dependent on the quality of development, availability and accessibility to social services and infrastructural facilities available (Greene and Rojas, 2008). International Longevity Centre (ILC) (2014) explained that living in a decent house is an indicator of wellbeing. Asiyanbola (2008) noted that many of the elderlies in Nigeria live in deplorable houses especially those in the rural areas. This implies that many of the elderlies in Nigeria are not living well. Therefore there is need for the elderlies especially those in the rural areas of Nigeria to live in decent houses.

\section{The Setting and Methodology}

Ibadan, which is the capital of Oyo state, is located on latitudes 7022' and 7040' North of the Equator and longitudes 3053' and $4^{\prime} 10^{\prime}$ East of the Greenwich. The city has five local government areas within its metropolis comprising Ibadan North, Ibadan Northeast, Ibadan North West, Ibadan South East and Ibadan South West and six in the hinter-land comprising Akinyele, Egbeda, Ido, Lagelu, Oluyole and Ona-ara Local Government areas. The location of Ibadan on the map of Oyo State is shown in Figure 1. 


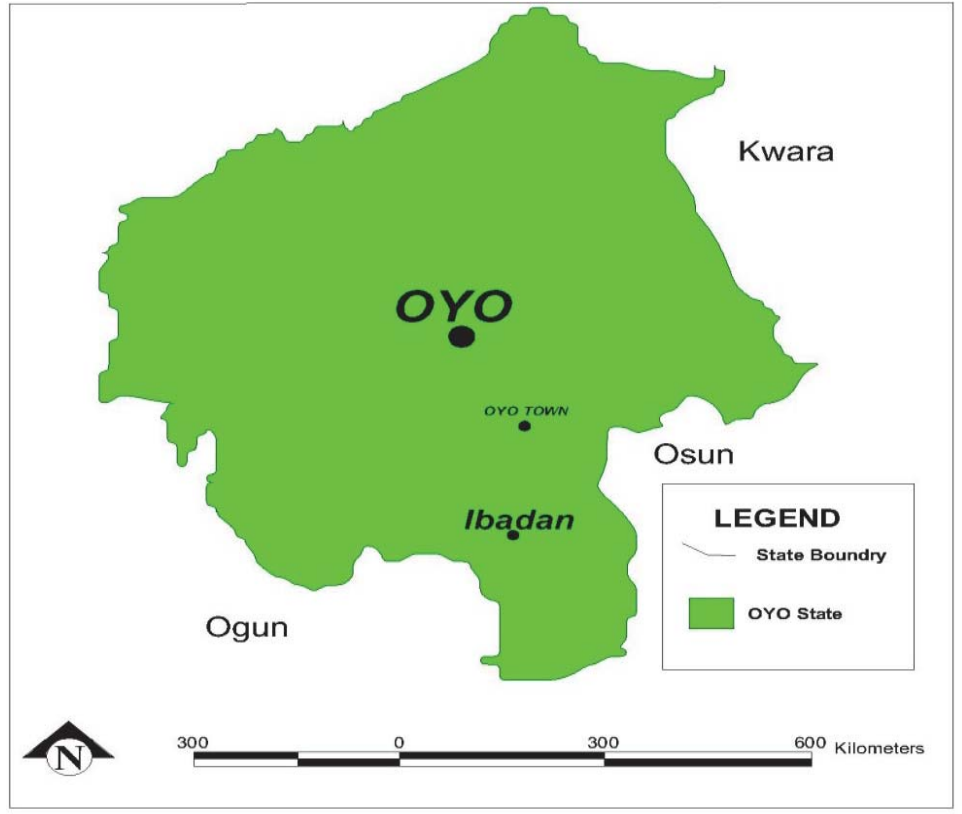

FIG 1: Location of Ibadan on the Map of Oyo State.

Multi-stage sampling technique was used for this study. Four of the six local government areas in the hinterlands of Ibadan (Akinyele, Egbeda, Ido, and Lagelu) were randomly selected. Three rural settlements were selected from each of the selected local government areas using simple random sampling method with no replacement so that all the settlements had equal chances of being selected. They are: Onidundu, Ojedeji, Obada, Idioro, Owobaale, Olodan, Ajiwogbo, Odebode, Elere, Odetola, Abaedun, Lalupon, and Oyedeji. The sampling frame was the total number of houses in the selected settlements while the sample size was determined by a snowball sampling technique where an elderly was located and the rest were referred in the study area. A total of 265 duly completed questionnaires administered to the elderly (age 60years and above) in each sampled household were used for data analysis. Where the respondents were not available, the next building was sampled.

\section{Results and Discussions}

First, frequency distribution of socio-economic characteristics and housing condition of the elderly were presented. This was followed by the determinants of housing habitability of the respondents, impact of the housing condition on the respondents and coping strategies of the respondents.

\subsection{Socio-Economic Characteristics of Respondents}

The socio-economic characteristics of the respondents analyzed in this section include; gender, age, education, marital status, occupation, income. The frequency distribution of these characteristics are as shown in Table 1below and are discussed subsequently. Gender analysis of the respondents revealed that $61.5 \%$ were females while $38.5 \%$ were males. This is an indication that there are more rural elderly females than males. This might be attributed to the fact that that most men in the rural areas have several wives. Also analysis of the respondents' age showed that $69 \%$ were in the 60 $80 y e a r s$ age bracket while the remaining $31 \%$ were in the age range 80 years and above.

Analysis of the educational status of the respondents revealed that $64.5 \%$ had no formal education, $4 \%$ attended primary schools, and $8 \%$ had tertiary education while the remaining (14.7\%) had vocational training. The low level of education might be one of the reasons (58.8\%) of the respondents were into farming (subsistence farming), trading $(25 \%)$, local crafts (11\%), hunting (3\%), transportation (1\%) and mixed occupation (1\%). There is every tendency to believe that the kind of occupation they do might have effect on their earnings. For instance, table 1 revealed that $40.4 \%$ 
earned less than $\mathrm{N} 100,000$ per annum. 38.1\% earned between $\mathrm{N} 100,000$ and $\mathrm{N} 200,000$ per annum while $6.8 \%$ earned about N400,000 and above per annum. The reason for their low annual income might also be attributed to their old age as well as small farm holdings which must have limited what they could do. Hence their low productivity and this indirectly influences their housing condition (See Table I).

Table 1: Socio-Economic Characteristics of Respondents

\begin{tabular}{|c|c|c|c|}
\hline Socio-Economic & Characteristics & Frequency & Percentage \\
\hline \multirow[t]{3}{*}{ Gender } & Male & 102 & 38.5 \\
\hline & Female & 163 & 61.5 \\
\hline & Total & 265 & 100 \\
\hline \multirow[t]{5}{*}{ Age } & $60-70$ years & 109 & 41.1 \\
\hline & 70-80years & 74 & 28.0 \\
\hline & 80-90years & 68 & 25.6 \\
\hline & 90 years + & 14 & 5.3 \\
\hline & Total & 265 & 100 \\
\hline \multirow[t]{6}{*}{ Education } & No formal Education & 171 & 64.5 \\
\hline & Vocational & 39 & 14.7 \\
\hline & Primary & 24 & 9.0 \\
\hline & Secondary & 11 & 4.2 \\
\hline & Tertiary & 20 & 7.6 \\
\hline & Total & 265 & 100 \\
\hline \multirow[t]{8}{*}{ Occupation } & Hunting & 7 & 2.6 \\
\hline & Farming & 156 & 58.8 \\
\hline & Local craft & 28 & 10.5 \\
\hline & Trading & 67 & 25.3 \\
\hline & Transportation & 3 & 1.1 \\
\hline & Mixed Occupation & 3 & 0.12 \\
\hline & Others & 1 & 0.4 \\
\hline & Total & 265 & 100 \\
\hline \multirow[t]{3}{*}{ Marital Status } & Married & 203 & 76.6 \\
\hline & Widowed & 62 & 23.4 \\
\hline & Total & 265 & 100 \\
\hline \multirow[t]{6}{*}{ Annual Income } & $<\mathrm{N} 100,000$ & 107 & 40.4 \\
\hline & N100,001- N200,000 & 101 & 38.1 \\
\hline & $\mathrm{N} 200,001-\mathrm{N} 300,000$ & 31 & 11.7 \\
\hline & $\mathrm{N} 300,001-\mathrm{N} 400,000$ & 8 & 3.0 \\
\hline & $>\mathrm{N} 400,001$ & 18 & 6.8 \\
\hline & Total & 265 & 100 \\
\hline
\end{tabular}

Source: Author's Field Survey, 2015

\subsection{Housing Conditions of Respondents}

Analysis of housing conditions of respondents were based on; material of construction of the houses, method of waste disposal, availability of housing amenities such as (water, electricity, sanitary facilities). The frequency distribution of these variables as shown in Table 2 revealed that the materials for construction of most of the houses were generally poor in the areas. $65.7 \%$ of the respondents had mud walls which in most cases have cracked or dilapidated while the remaining $34.3 \%$ had sandcrete walls. $56.6 \%$ had bare ground for their floors. The condition of most of the buildings (75.4\%) were generally poor. The reason for this is not far-fetched from the materials used for construction since many of them (65.7\%) used mud for their walls which has an average life-span of 50years (Fadamiro, 2002). 
Table 2: Housing Condition Characteristics of Respondents

\begin{tabular}{|c|c|c|c|}
\hline \multicolumn{2}{|c|}{ Housing Condition Characteristics } & \multirow{3}{*}{$\begin{array}{c}\text { Frequency } \\
91\end{array}$} & \multirow{2}{*}{ Percentage } \\
\hline \multicolumn{2}{|c|}{ 1. Materials for Construction } & & \\
\hline \multirow[t]{3}{*}{ Wall materials } & Sandcrete & & 34.3 \\
\hline & Mud & 174 & 65.7 \\
\hline & Total & 265 & 100 \\
\hline \multirow[t]{4}{*}{ Floor materials } & Concrete & 2 & 0.8 \\
\hline & Cement/sand & 113 & 42.6 \\
\hline & Bare ground & 150 & 56.6 \\
\hline & Total & 265 & 100 \\
\hline \multirow[t]{4}{*}{ Condition of building } & Good & 30 & 11.3 \\
\hline & Fair & 35 & 13.2 \\
\hline & Poor & 200 & 75.4 \\
\hline & Total & 265 & 100 \\
\hline \multicolumn{4}{|l|}{ 2. Housing Amenities } \\
\hline \multirow[t]{4}{*}{ Water supply } & Public tap & 31 & 11.7 \\
\hline & Hand dug well & 168 & 63.3 \\
\hline & Stream & 66 & 25.0 \\
\hline & Total & 265 & 100 \\
\hline \multirow[t]{4}{*}{ Toilet facilities } & Pit/latrines & 53 & 20.0 \\
\hline & Bush/dunghills & 196 & 74.0 \\
\hline & Streams/drainage & 16 & 6.0 \\
\hline & Total & 265 & 100 \\
\hline \multirow[t]{3}{*}{ Bathroom facilities } & Open/Outside & 252 & 95.0 \\
\hline & Indoor & 13 & 5.0 \\
\hline & Total & 265 & 100 \\
\hline \multirow[t]{4}{*}{ Waste disposal } & Streams & 22 & 8.0 \\
\hline & Burning & 37 & 14.0 \\
\hline & Open space & 206 & 78.0 \\
\hline & Total & 265 & 100 \\
\hline \multirow[t]{4}{*}{ Illumination facilities } & IBEDC & 100 & 37.7 \\
\hline & Self-generating plant & 17 & 6.4 \\
\hline & Clay lamp/lantern & 148 & 55.9 \\
\hline & Total & 265 & 100 \\
\hline
\end{tabular}

Source: Author's Field Survey, 2015

Also analysis of housing amenities revealed that $63.3 \%$ of the respondents had their water supply from hand dug well which was usually not treated and $25 \%$ got theirs from the stream. The respondents explained that they trekked long distances (which most times is not less than 30minutes) in accessing the available wells and streams. They also complained that most times the water gotten from the streams and wells in most cases are usually not in good state. For instance the water from the wells are muddy and the water from streams are usually greenish in color because of water weeds.

Also $74 \%$ of the respondents used bush/dunghills as their toilet, $20 \%$ had and used pit latrines, $6 \%$ used streams in their houses. Also most of the respondents (95\%) used open/outside bathrooms which in most cases are built like shed. The 'shed like' bathroom were constructed with palm fronds or iron sheets many of which are without roofs. The remaining $5 \%$ had indoor bathrooms many of which are detached from the main building. Majority of the respondents (78\%) used open space for their waste disposal, $14 \%$ burnt their waste while $8 \%$ disposed theirs in streams.

Analysis of illumination facilities revealed that only $37.7 \%$ had access to electricity through Ibadan Electricity Distribution Company (IBEDC), $6.4 \%$ had access to electricity through self- generating plants while the rest (55.9\%) could not access electricity but made use of clay lamps or Lantern.

Assessment of building condition in the study area revealed that $67 \%$ of the houses needs to be completely replaced because many of the walls were cracked and dilapidated and the roofs were in state of disrepair. $26 \%$ needs major renovation while $7 \%$ needs minor repairs. From the above analysis, housing condition of the rural elderly in the study area are in bad state. 


\subsection{Determinants of Housing Habitability of the Elderly in Selected Rural Communities of Ibadan, Oyo State.}

Several factors contributes to housing inhabitability of the elderly in the rural areas. In determining these factors, socioeconomic variables were correlated with some variables of housing condition. The dependent variables were the selected variables of housing condition of the elderly (materials for construction, housing amenities) while the independent variables were the socio-economic characteristics of the respondents. The result as shown in Table 3 revealed that wall materials correlated with marital status $\left(0.193^{\star *}\right)$, annual income $\left(0.270^{* *}\right)$ and negatively with age $\left(-0.230^{\star *}\right)$ at 0.01 level of significance and gender $\left(0.147^{\star}\right)$ at 0.05 level of significance. This implies that when they are not widowed, the better their wall materials for construction. The higher their annual income, the better the materials used for their wall construction while the higher their age, the poorer the materials of wall construction in the houses they live. Also, floor materials correlated negatively with age $\left(-0.126^{*}\right)$, marital status $\left(-0.146^{*}\right), p \leq 0.05$ and income $\left(0.202^{* *}\right)$ at $p \leq 0.01$. This indicates that the higher their age and marital status the poorer their floor materials and also the higher their income, the better the floor materials. The table also showed that the condition of building correlated with age $\left(-0.330^{\star *}\right)$, gender $\left(0.196^{\star *}\right)$, annual income $\left(-0.168^{\star *}\right)$ at $p \leq 0.01$ and marital status $\left(0.126^{*}\right)$ at $p \leq 0.05$. This also suggests that the higher their marital status the better their condition of buildings while the lower their income and the age of the elderly, the poorer the condition of building.

Table 3: Correlation Coefficients of Materials for construction and Socio-Economic Characteristics of the Elderly

\begin{tabular}{|l|c|c|c|c|c|c|}
\hline Materials for construction & Gender & Age & Education & Occupation & Annual income & Marital status \\
\hline Wall materials & $0.147^{\star}$ & $-0.230^{\star *}$ & -0.045 & -0.072 & $0.270^{\star *}$ & $0.193^{\star \star}$ \\
\hline Floor materials & -0.016 & $-0.126^{\star}$ & -0.042 & 0.010 & $0.202^{\star *}$ & $-0.146^{\star}$ \\
\hline Condition of Building & $0.196^{\star \star}$ & $-0.330^{\star \star}$ & -0.112 & -0.110 & $-0.168^{\star *}$ & $0.126^{\star}$ \\
\hline
\end{tabular}

*Significant at 0.05 ; ** Significant at 0.01

Source: Author's Field survey, 2015

Furthermore, analysis of housing amenities and socio-economic characteristics of the elderly in Table 4 revealed that age $\left(-0.335^{\star *}\right)$ negatively correlated with water supply at $p \leq 0.01$. Annual income $\left(0.268^{\star \star}\right)$ and education $\left(0.123^{\star}\right)$ correlated with water supply at $p \leq 0.01$ and $p \leq 0.05$ respectively. This suggests that the higher their age, the poorer their access to water supply. Also the higher their annual income and educational status, the better their access to water supply. Age ($\left.0.338^{\star \star}\right)$ and Annual income $\left(0.227^{\star *}\right)$ correlated with Toilet facilities at $p \leq 0.01$ level of significance. This also suggests that the older they are, the poorer the toilet facilities and the higher their income the better their toilet facilities. Gender $\left(0.066^{\star *}\right)$ and Age $\left(-0.212^{\star *}\right)$ correlated with bathroom facilities at $p \leq 0.01$ level of significance. This shows the higher their age, the poorer the bathroom facilities available and also being a man or woman determines the type of bathroom facilities available in each household. Also, the method of waste disposal correlated with age $\left(0.175^{\star *}\right)$ and Occupation $\left(0.223^{\star \star}\right)$ at $p \leq 0.01$. This means the method of waste disposal adopted by each household is determined by their age and the type of occupation they engage in. The higher their age and better occupation, the better their method of waste disposal. Finally, illumination facilities correlated with age $\left(0.239^{\star *}\right)$, educational status $\left(0.184^{\star \star}\right)$ annual income $\left(0.294^{\star \star}\right)$ at $p \leq 0.01$ and marital status $\left(0.138^{\star}\right)$ at $p \leq 0.05$ level of significance. This implies the higher their age, education, annual income and marital status, the better their illumination facilities.

Table 4: Correlation Coefficients of Housing Amenities and Socio-Economic Characteristics of the Elderly

\begin{tabular}{|l|c|c|c|c|c|c|}
\hline Sanitary services & Gender & Age & Education & Occupation & Annual income & Marital status \\
\hline Water Supply & 0.064 & $-0.335^{\star \star}$ & $0.123^{\star}$ & -0.041 & $0.268^{\star *}$ & 0.067 \\
\hline Toilet Facilities & 0.094 & $-0.338^{\star *}$ & -0.027 & -0.035 & $0.227^{* *}$ & -0.027 \\
\hline Bathroom Facilities & $0.066^{\star *}$ & $-0.212^{\star *}$ & -0.024 & 0.162 & -0.005 & -0.010 \\
\hline Waste Disposal & 0.096 & $0.175^{\star \star}$ & 0.049 & $0.223^{\star *}$ & 0.001 & 0.050 \\
\hline Illumination facilities & 0.073 & $0.239^{\star \star}$ & $0.184^{\star *}$ & 0.033 & $0.294^{\star *}$ & $0.138^{\star}$ \\
\hline
\end{tabular}

*Significant at 0.05, **Significant at 0.01

Source: Author's Field Survey, 2015 


\section{Discussion}

The above findings revealed that housing condition of the elderly in the selected rural communities were generally poor and in a state of disrepair. Majority of the houses need to be completely replaced while many need major renovation and very few need minor repairs. The reason for this is because many of the elderlies used poor materials for their housing construction and also dwell in houses with unavailable, poor or non-functional housing amenities. This can be attributed to the poor socio-economic status of the rural elderly. For instance, it was discovered in the study that the higher their annual income, the better the materials used for their wall and floor construction and also the better their condition of building. Also the older the elderly, the poorer their wall and floor materials and the poorer their condition of buildings.

Furthermore, analysis of housing amenities and socio-economic characteristics of the elderly revealed that the older they are, the poorer their bathroom and toilet facilities and their access to water supply. Also the higher their annual income and educational status, the better their toilet, bathroom and illumination facilities, and also their access to water supply. Finally, the higher their age and occupation, the better their method of waste disposal.

Consequently, from this study, it can be concluded that many of the rural elderly's houses are uninhabitable, in other words, they are facing housing habitability challenges and thus are not living well. This is in line with Greene and Rojas (2008) which explained that well-being is largely determined by the condition of housing occupied which in turn is dependent on the quality of development, availability and accessibility to social services and infrastructural facilities available. In a nut shell, the housing habitability of the rural elderly is a reflection of their socio-economic status and their access to social services and infrastructural facilities.

\section{Conclusion and Policy Implications}

The housing habitability of the elderly in selected rural communities of Oyo State have been examined in this study. In order to examine the housing habitability of the elderly in the rural areas, their housing condition and the determinants of their housing condition were examined. The housing condition characteristics of the respondents examined were; waste disposal, housing amenities (water, electricity, sanitary facilities) and building materials. The major determinants of housing condition of the elderly men and women in the study area were identified. It was discovered in this study that the higher the age of the elderly in the study area, the poorer their toilet facilities, bathroom facilities, illumination facilities and access to water supply in the study area. Also the higher their annual income and educational status the better their access to water supply, toilet facilities and illumination facilities. Also being a man or woman determines the type of bathroom facilities available in each household. The method of waste disposal adopted by each household is also determined by their age and the type of occupation they engage in.

Therefore, banks, cooperative societies and housing cooperatives should be established and the rural elderlies should be allowed to have access to bank loans, credit facilities and building materials to build/rebuild their houses. Many of the houses need to be completely replaced while very few needs renovation. Also, rural housing programs where people are trained in the act of using modern materials to build houses should as well be encouraged. Finally, functional housing amenities like electricity, water facilities, and waste disposal facilities should be provided to the rural settlements and everybody must have access to such facilities especially the rural elderly. For future studies, it may be necessary to skew rural studies towards the elderly in the rural areas so that they are not marginalized.

\section{References}

Akinola, S.R. (1998): The pattern of housing quality in Osogbo, Osun State, Nigeria. Ife Journal of Environmental Design and Management, Vol. 1, Nos 1 and 2, Pp. 109-120.

Aribigbola, A. (2008): Housing Policy Formulation in Developing Countries: Evidence of Programme Implementation for Akure, Ondo State, Nigeria. Journal of Humanities and Ecology, 23 (2), 125 - 134.

Asiyanbola, AR. (2008): Assessment of Family Care, Housing, Gender, Daily Activities, and Physical Wellbeing of the Elderly in Ibadan, Nigeria. An International Journal of Agricultural Sciences, Sciences Environment and Technology. Vol 3, No 1.

Banks, James, Richard B., Zoe O., and James P. S. (2012): "Housing Mobility and Downsizing at Older Ages in Britain and the USA," Economical 79 (313): 1-26.

Eke, F. (2004): Rental Housing an option for Developing Council-Africa. A paper presented on behalf of the National Union of Tenants of Nigeria at the International Union of Tenants (IUT) Congress in England from the $5^{\text {th }}-8^{\text {th }}$ August.

Fadamiro, J.A. (2001): An Appraisal of Architectural Principles in the Provision and Maintenance of Affordable Rural Housing. Paper presented at the National Conference on Rural Environment and Sustainable Development, University of Ado-Ekiti, Nigeria.

Gardiner, S. H. (2004): Elderly: Public Housing and Assisted Living, a Timely Collaboration for Aging Seniors. Boston: The Center Point 
Foundation.

Greene, M. and Rojas, E. (2008):"Incremental housing in Chile 1990-2002", Technical Notes, Inter-American Development Bank, Department of Sustainable Development, Washington DC.

IFAD (2007): Rural poverty portal; Geography, agriculture and the economy. International Longevity Centre (ILC), (2014):

Kolawole, O. D and Torimiro, D.O (2006): Crucial factors associated with participatory rural employment promotion in some selected communities of Lagos State, Technical Report, Centre for Rural Development (CERUD), Lagos, Nigeria, pp2-48.

Lloyd-Sherlock P. Old age and poverty in developing countries: new policy challenges. World Development. 2000;28 (12):2157-68.

Meng, G. H., G.B and Roberts, S. (2006): "Multi-group segregation indices for measuring Ordinal classes", Computers, Environment and Urban Systems, 30, 275-299. Federal Republic of Nigeria (FGN, 2006), National Housing Policy, Abuja

Nubi, O.T. (2008): Affordable Housing Delivery in Nigeria. The South African Foundation International Conference and Exhibition Cape Town. Pp 1-18.

Oldman, J. (2014): Housing in later life - Age UK

Painter, G. and Lee K. (2009): "Housing Tenure Transitions of Older Households Life Cycle, Demographic, and Familial Factors," Regional Science and Urban Economics, forthcoming.

UN HABITAT (2009): Planning sustainable cities: Policy directions global report on human settlements.

Wahab, B. (2001): Grassroots Participation in Sustainable Urban Development of Slum and Squatter Settlement. Paper presented at the 32 And Annual Conference of the Nigerian Institute of Town Planners, Uyo, Akwa Ibom State.

W.H.O. (1961): World Health Organization. Technical Report Series no. 225.

World Bank, (1994): Averting the Old Age Crisis: Policies to protect the old and promote Growth (Washington D.C, Oxford). World Bank, (2000): World Development Report, 2000/2001: Attacking poverty. Washington DC. World Bank 